\title{
Identification and Shipment Progress of The INL and LANL Samples to Be Received at ORNL
}

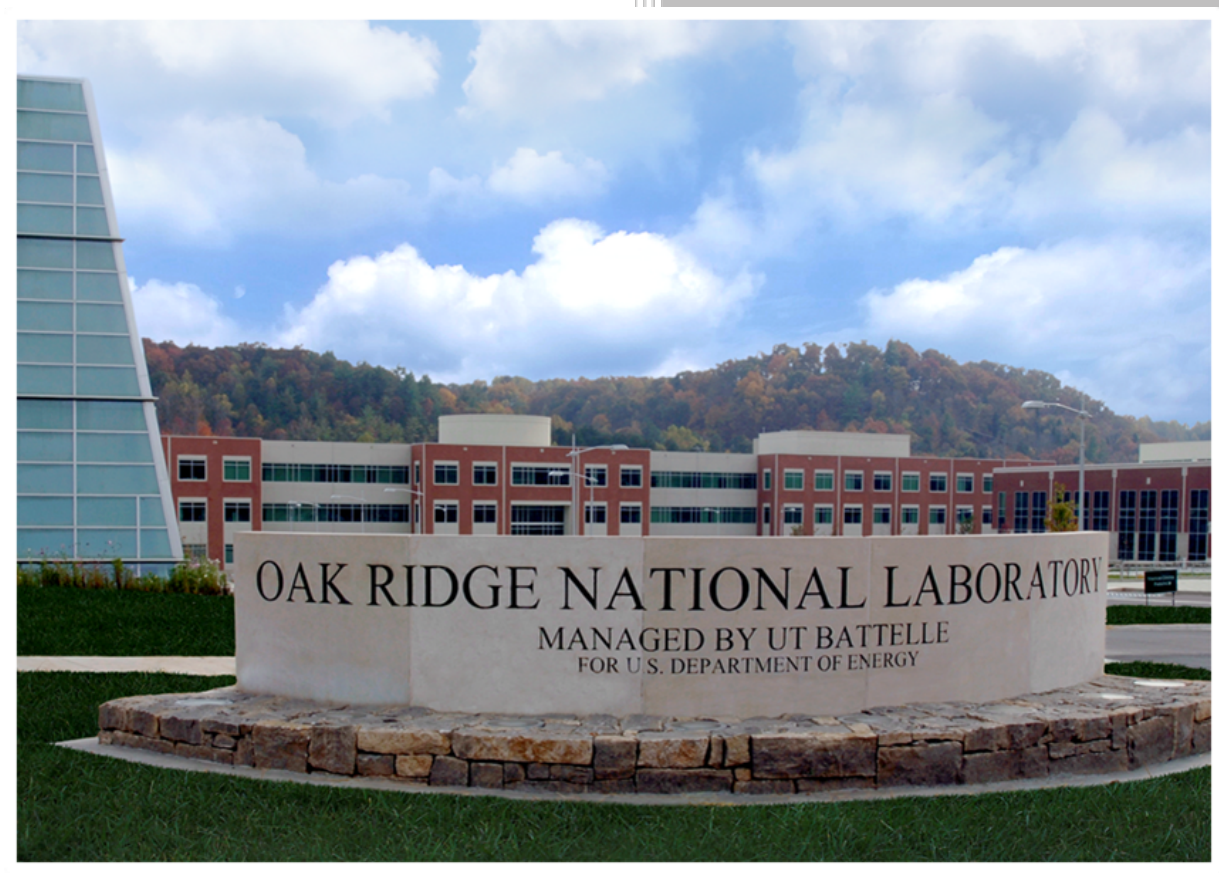

Approved for public release. Distribution is unlimited.
Lizhen Tan

Kory Linton

Oak Ridge National Laboratory

Collin J. Knight

Idaho National Laboratory

Tarik A. Saleh

Los Alamos National Laboratory

February 28, 2019 


\title{
DOCUMENT AVAILABILITY
}

Reports produced after January 1, 1996, are generally available free via US Department of Energy (DOE) SciTech Connect.

Website www.osti.gov

Reports produced before January 1, 1996, may be purchased by members of the public from the following source:

\author{
National Technical Information Service \\ 5285 Port Royal Road \\ Springfield, VA 22161 \\ Telephone 703-605-6000 (1-800-553-6847) \\ TDD 703-487-4639 \\ Fax 703-605-6900 \\ E-mail info@ntis.gov \\ Website http://classic.ntis.gov/
}

Reports are available to DOE employees, DOE contractors, Energy Technology Data Exchange representatives, and International Nuclear Information System representatives from the following source:

Office of Scientific and Technical Information

PO Box 62

Oak Ridge, TN 37831

Telephone 865-576-8401

Fax 865-576-5728

E-mail reports@osti.gov

Website http://www.osti.gov/contact.html

This report was prepared as an account of work sponsored by an agency of the United States Government. Neither the United States Government nor any agency thereof, nor any of their employees, makes any warranty, express or implied, or assumes any legal liability or responsibility for the accuracy, completeness, or usefulness of any information, apparatus, product, or process disclosed, or represents that its use would not infringe privately owned rights. Reference herein to any specific commercial product, process, or service by trade name, trademark, manufacturer, or otherwise, does not necessarily constitute or imply its endorsement, recommendation, or favoring by the United States Government or any agency thereof. The views and opinions of authors expressed herein do not necessarily state or reflect those of the United States Government or any agency thereof. 
ORNL/LTR-2019/1083

M4NA-17OR0204015

FY 2017 Consolidated Innovative Nuclear Research (CINR)

Nuclear Science User Facilities (NSUF)

Light Water Reactor Sustainability (LWRS)

\title{
IDENTIFICATION AND SHIPMENT PROGRESS FOR THE INL AND LANL SAMPLES TO BE RECEIVED AT ORNL
}

\author{
Lizhen Tan and Kory Linton \\ Oak Ridge National Laboratory \\ Collin Knight \\ Idaho National Laboratory \\ Tarik Saleh \\ Los Alamos National Laboratory
}

Date Published: February 28, 2019

Prepared by

OAK RIDGE NATIONAL LABORATORY

Oak Ridge, TN 37831-6283

managed by

UT-BATTELLE, LLC

for the

US DEPARTMENT OF ENERGY

under contract DE-AC05-00OR22725 



\section{CONTENTS}

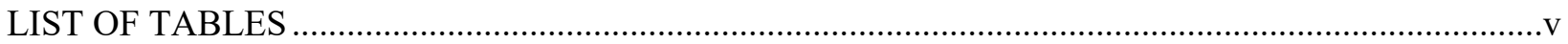

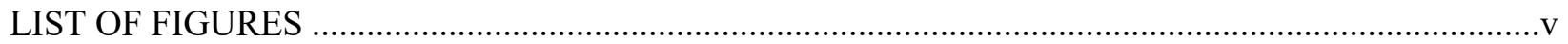

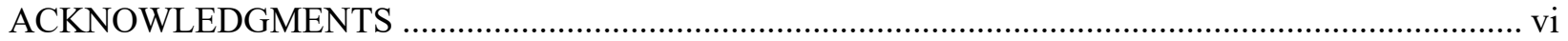

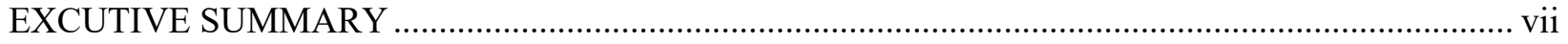

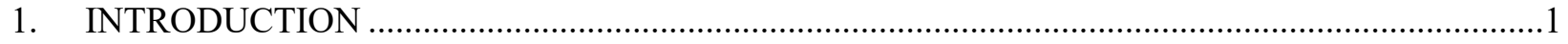

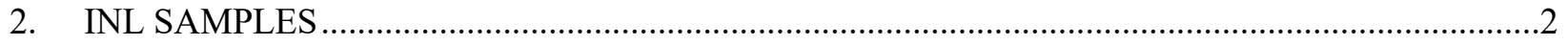

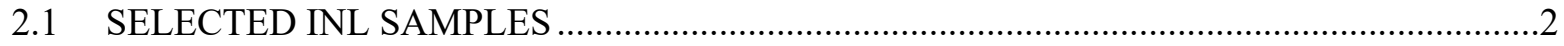

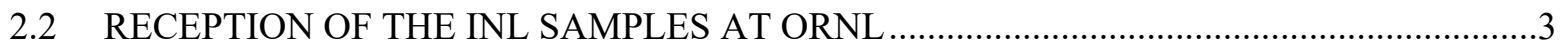

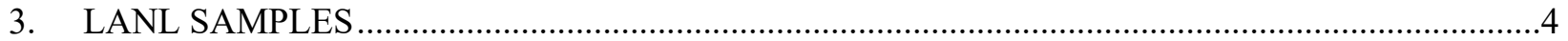

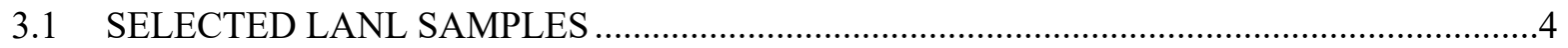

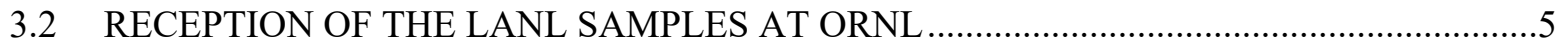

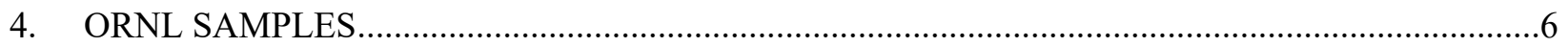

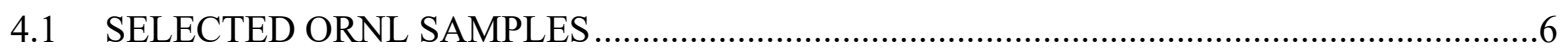

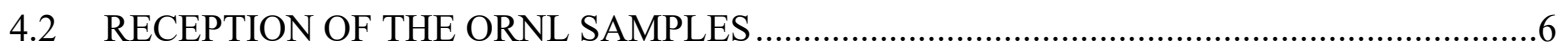

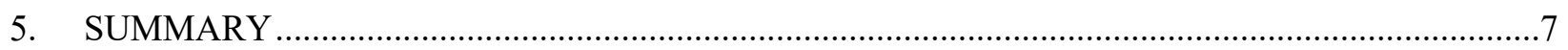

REFERENCE 


\section{LIST OF TABLES}

Table 1. Selected INL samples. .2

Table 2. Compositions in weight percent (wt \%) of the INL samples, with Fe as balance* ..........................

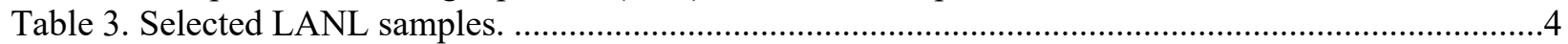

Table 4. Compositions in weight percent (wt \%) of the LANL samples, with Fe as balance.......................

Table 5. Selected ORNL samples. ....................................................................................................6

Table 6. Compositions in weight percent (wt\%) of the ORNL samples, with Fe as balance......................6

\section{LIST OF FIGURES}

Figure 1. Irradiation temperature and dose conditions of the selected Grade 92, T91, 800H, and $800 \mathrm{H}-\mathrm{TMP}$ samples. 


\section{ACKNOWLEDGMENTS}

This research was sponsored by the U.S. Department of Energy (DOE), Office of Nuclear Energy (NE), the FY 2017 Consolidated Innovative Nuclear Research (CINR) Nuclear Science User Facilities (NSUF) program and the Light Water Reactor Sustainability (LWRS) program. We gratefully acknowledge the support provided by Alison Hahn of DOE-NE and Rory Kennedy of Idaho National Laboratory for the NSUF access support and Keith Leonard of Oak Ridge National Laboratory (ORNL) for the research and development support of this project.

The authors are grateful to Kurt Terrani, NSUF technical leader of ORNL, for supporting this project and Alicia Raftery, Ben Garrison, Clay Morris, Mark Delph, Patricia Tedder, and Joshua Schmidlin of ORNL for sample sorting and reception. Kevin Field and Xiang Chen of ORNL are appreciated for technical review of this report. 


\section{EXCUTIVE SUMMARY}

Ferritic-martensitic steel Grade 92, with T91 as a reference, together with austenitic stainless steel (or Incoloy Alloy) $800 \mathrm{H}$ and its grain-boundary-engineered version $800 \mathrm{H}-\mathrm{TMP}$ (ThermoMechanical Processing), is investigated in this project. A total of fifteen Grade 92 samples from two or three heats, four T91 samples from two heats, and six $800 \mathrm{H}$ and six $800 \mathrm{H}-\mathrm{TMP}$ samples from one heat were selected, which were primarily irradiated in the Advanced Test Reactor of Idaho National Laboratory (INL), with the rest in the High Flux Isotope Reactor of Oak Ridge National Laboratory (ORNL), BOR-60 of Russia, and Phénix reactor of France. The samples were irradiated in the temperature range of 241 to $720^{\circ} \mathrm{C}$ and a dose range of 1.28 to $\sim 70$ displacements per atom.

All the INL samples, most of the ORNL samples, and part of the LANL (Los Alamos National Laboratory) samples from the ATR, BOR-60 and Phénix reactors have been received at the Irradiated Materials Examination and Testing (IMET) hot cell facility and Low Activation Materials Design and Analysis (LAMDA) laboratory of ORNL. Post-irradiation examination of the received samples is in progress at ORNL. The effects of irradiation temperature, dose, reactor (e.g., dose rate, neutron-spectrum-induced difference in transmutation), TMP, and heats variation on the microstructures and mechanical properties of the samples will be evaluated. 


\section{INTRODUCTION}

Advanced alloys are desired to provide greater safety margins, design flexibility and economics compared to traditional reactor materials. Grade 92 ferritic-martensitic steel and austenitic Alloy 800/800H are two of the promising alloys interested by the current Advanced Radiation-Resistant Materials (ARRM) and Light Water Reactor Sustainability (LWRS) programs. However, systematic studies on neutron-irradiation induced changes in microstructures and mechanical properties are deficient for the alloys. The objective of this project is to develop correlations between microstructures and mechanical properties of the neutronirradiated Grade 92 and Alloy $800 / 800 \mathrm{H}$, based on the experimental results generated from this work. It is expected to develop broader correlations for these types of steels by comparing the results of this work with that of similar alloys such as Grade 91, Alloy 709 and type 304/316 stainless steels from literature and the ongoing studies, with the aid of thermodynamics, kinetics, and microstructural hardening modeling.

Samples of Grade 92 and Alloy $800 \mathrm{H}$ selected in this work were primarily irradiated in two test reactors for up to $\sim 14$ displacements per atom (dpa) at $\sim 241-720^{\circ} \mathrm{C}$. Samples of Grade 91, irradiated in the same reactors, were selected as references of Grade 92 . Few samples from other two reactors will be included for comparison. Both irradiated and unirradiated samples from the same heat of the materials will be examined to elucidate the radiation-induced evolutions in microstructures, mechanical properties, and deformation mechanisms. To be more specific, mechanical properties such as tensile properties, modulus, hardness, and viscoplasticity will be measured through tensile, Vickers hardness and nanoindentation tests. Microstructural characterization of the samples will be carried out using the state-of-the-art instruments and techniques provided through the Nuclear Science User Facilities (NSUF). The obtained experimental results will then be used to establish the knowledgebase on the effects of alloy chemistry, thermomechanicalprocessing, and irradiation conditions on microstructures and mechanical properties of Grade 92 and Alloy $800 \mathrm{H}$.

Outcomes of this project will include a comprehensive set of data including microstructures and mechanical properties of both irradiated and unirradiated samples of the interested steels, which will not only help understanding the essential performance of similar alloys, but more importantly to gain indispensable insights into the development of advanced alloys with superior radiation resistance. The outcomes can also serve as inputs and/or benchmarks for microstructural and mechanical property modeling of irradiated ferritic-martensitic and austenitic steels. The accomplishment of this project will directly benefit the LWRS program and bring values to the Advanced Reactor Technologies and Small Modular Reactors programs.

Procurement of the interested neutron-irradiated samples is a critical step to accomplish the goal of this project. This report summarizes the identification and shipment progress for the interested samples at Idaho National Laboratory (INL), Los Alamos National Laboratory (LANL), and Oak Ridge National Laboratory (ORNL), which are to be received and examined at ORNL for this project. 


\section{INL SAMPLES}

\subsection{SELECTED INL SAMPLES}

A total of twelve INL samples of steels $800 \mathrm{H}$, NF616, and T91 were selected, which were irradiated in the Advanced Test Reactor (ATR) of INL through the University of Wisconsin Pilot Project of the ATR National Scientific User Facility [1]. The steels 800H, NF616, and T91 were commercial heats distributed by INL, Japan Atomic Energy Agency (JAEA), and INL, respectively. The selected samples are listed in Table 1. The samples are in two types, with one type as type SS-J2 miniature specimens and the other type as 3-mm diameter discs.

Table 1. Selected INL samples.

\begin{tabular}{|c|c|c|c|c|c|c|c|c|}
\hline \multirow[b]{2}{*}{ Specimen type } & \multirow[b]{2}{*}{ Alloy } & \multirow{2}{*}{$\begin{array}{c}\text { Engraved } \\
\text { sample } \\
\text { code }\end{array}$} & \multirow{2}{*}{$\begin{array}{l}\text { KGT } \\
\text { Num }\end{array}$} & \multicolumn{2}{|c|}{ Temperature $\left({ }^{\circ} \mathrm{C}\right)$} & \multicolumn{2}{|c|}{ Dose (dpa) } & \multirow{2}{*}{$\begin{array}{c}\text { Dose rate } \\
(\mathrm{dpa} / \mathrm{s})\end{array}$} \\
\hline & & & & Planned & $\begin{array}{l}\text { Average } \\
\text { as-run }\end{array}$ & Planned & $\begin{array}{l}\text { As-run } \\
\text { total }\end{array}$ & \\
\hline \multirow{10}{*}{$\begin{array}{c}\text { Type SS-J2 } \\
\text { miniature tensile } \\
\text { specimen with } 16 \times \\
4 \times(<1) \text { mm and } \\
\text { gauge } 5 \times 1.2 \times \\
\quad(<1) \mathrm{mm} .\end{array}$} & \multirow{3}{*}{$800 \mathrm{H}$} & N4 & 1712 & 400 & 359 & 6 & 7.27 & $1.30 \times 10^{-7}$ \\
\hline & & N5 & 1772 & 500 & 451.5 & 3 & 3.9 & $1.35 \times 10^{-7}$ \\
\hline & & N6 & 1806 & 500 & 431 & 6 & 9.01 & $1.61 \times 10^{-7}$ \\
\hline & \multirow{3}{*}{$\begin{array}{l}800 \mathrm{H}- \\
\text { TMP }\end{array}$} & $\mathrm{P} 4$ & 2578 & 400 & 359 & 6 & 7.36 & $1.31 \times 10^{-7}$ \\
\hline & & P5 & 2596 & 500 & 451.5 & 3 & 3.95 & $1.37 \times 10^{-7}$ \\
\hline & & P6 & 2597 & 500 & 431 & 6 & 9.12 & $1.63 \times 10^{-7}$ \\
\hline & \multirow{4}{*}{ NF616 } & $\mathrm{D} 1^{*}$ & 402 & 300 & 241 & 3 & 3.51 & $1.29 \times 10^{-7}$ \\
\hline & & D2 & 1791 & 300 & 291.5 & 6 & 2.96 & $5.29 \times 10^{-8}$ \\
\hline & & D4 & 1735 & 400 & 359 & 6 & 5.91 & $1.06 \times 10^{-7}$ \\
\hline & & D6 & 1783 & 500 & 431 & 6 & 8.16 & $1.46 \times 10^{-7}$ \\
\hline \multirow{2}{*}{$\begin{array}{l}\text { 3-mm diameter disc } \\
\text { ( } \sim 0.2-\mathrm{mm} \text { thick })\end{array}$} & \multirow{2}{*}{ T91 } & $\mathrm{A} 4$ & 1729 & 400 & 447.5 & 6 & 4.78 & $8.51 \times 10^{-8}$ \\
\hline & & A6 & 1790 & 500 & 429.5 & 6 & 7.79 & $1.39 \times 10^{-7}$ \\
\hline
\end{tabular}

* The sample D1 is at Argonne National Laboratory (ANL), which is to be in-situ tensile-tested during highenergy x-ray diffraction using the Advanced Photon Source (APS) of ANL.

Other than the standard solution-annealed condition $\left(1177^{\circ} \mathrm{C}\right.$ for 24 minutes per centimeter of thickness, followed by a water quench) of austenitic stainless steel $800 \mathrm{H}$, a thermomechanically processed (TMP) condition, named as $800 \mathrm{H}-\mathrm{TMP}$, was irradiated simultaneously. The TMP was constituted of a $6.6 \pm 0.2 \%$ thickness reduction by rolling at room temperature, followed by annealing at $1050^{\circ} \mathrm{C}$ for 90 minutes and water quench, which is a grain boundary engineering (GBE) method to significantly increase the fraction of low- $\Sigma$ coincidence site lattice (CSL) boundaries, e.g., nearly $70 \%(800 \mathrm{H}-\mathrm{TMP})$ and $\sim 40 \%$ ( $800 \mathrm{H})$ low$\Sigma$ CSL boundaries [2]. GBE with a significantly increased fraction of low- $\Sigma$ CSL boundaries would benefit a variety of properties such as strength and resistance to creep, stress corrosion cracking, and oxidation [3]. The $800 \mathrm{H}$-TMP exhibited noticeable enhancements in the resistance to thermal aging [4] and corrosion in supercritical water and high-temperature air $[5,6,7,8]$. Preliminary studies also showed more or less improvements in resistance to neutron irradiation $[9,10]$. Therefore, three samples of $800 \mathrm{H}-\mathrm{TMP}$, together with three samples of $800 \mathrm{H}$ irradiated in nearly identical conditions, were selected in this project to confirm and elucidate the beneficial effects of GBE/TMP on the neutron irradiation resistance of $800 \mathrm{H}$. The other set of samples are ferritic-martensitic steels NF616 and T91, classic/typical versions of Grade 92 and 91, respectively. T91 samples are to be used as reference for NF616.

Each sample was engraved with a unique sample code for visual sample identification and assigned with a unique KGT number for sample library record. The information, together with the planned and as-run irradiation temperature and dose listed in Table 1, was obtained from the material library presented online 
at https://nsuf.inl.gov. The dose rate in Table 1 was deduced from as-run neutron fluence divided by irradiation time. The irradiation conditions, e.g., temperature and dose, will be compared with the analytical reports of the University of Wisconsin Pilot Project $[11,12,13]$.

The compositions in weight percent (wt $\%$ ) of $800 \mathrm{H}$, NF616, and T91 of the INL samples are listed in Table 2 [1]. The compositions are critical for alloy thermodynamic analysis and transmutation analysis to interpret the experimental observations in this project.

Table 2. Compositions in weight percent (wt\%) of the INL samples, with Fe as balance*.

\begin{tabular}{|c|c|c|c|c|c|c|c|c|c|c|c|c|c|c|c|}
\hline Alloy & $\mathrm{Cr}$ & $\mathrm{Ni}$ & $\mathrm{Mn}$ & $\mathrm{Si}$ & $\mathrm{Ti}$ & $\mathrm{Al}$ & $\mathrm{V}$ & $\mathrm{W}$ & $\mathrm{Mo}$ & $\mathrm{Nb}$ & $\mathrm{Cu}$ & $\mathrm{C}$ & $\mathrm{N}$ & $\mathrm{P}$ & $\mathrm{S}$ \\
\hline 800H/800-TMP & 20.42 & 31.59 & 0.76 & 0.13 & 0.57 & 0.50 & & & & & 0.42 & 0.069 & & 0.014 & 0.001 \\
\hline NF616 & 8.82 & 0.174 & 0.45 & 0.102 & & 0.005 & 0.194 & 1.87 & 0.468 & 0.064 & & 0.109 & 0.0474 & 0.012 & 0.0032 \\
\hline T91 & 8.37 & 0.21 & 0.45 & 0.28 & & 0.022 & 0.216 & & 0.90 & 0.076 & 0.17 & 0.1 & 0.048 & 0.009 & 0.003 \\
\hline
\end{tabular}

${ }^{*}$ The blank cells are the elements not measured or reported. Oxygen and boron contents were reported as $0.0042 \%$ and $0.0017 \%$, respectively, in NF616, which were not reported in the other alloys. $800 \mathrm{H}$ was solution-annealed at $1177^{\circ} \mathrm{C}$ for 24 minutes per centimeter of thickness, followed by a water quench. $800 \mathrm{H}$-TMP was based on $800 \mathrm{H}$, subjected to $\sim 6.6 \%$ thickness reduction by rolling at room temperature and then annealed at $1050^{\circ} \mathrm{C}$ for $1.5 \mathrm{~h}$ with water quench. NF616 was normalized at $1070^{\circ} \mathrm{C}$ for $2 \mathrm{~h}$ and tempered at $770^{\circ} \mathrm{C}$ for $2 \mathrm{~h}$ with air cooling. T91 was normalized at $1066^{\circ} \mathrm{C}$ for $0,8 \mathrm{~h}$ and tempered at $790^{\circ} \mathrm{C}$ for $0.7 \mathrm{~h}$ with air cooling.

\subsection{RECEPTION OF THE INL SAMPLES AT ORNL}

One of the NF616 samples, with an engraved sample code of D1, is at ANL, which will be examined by in-situ tensile test during high-energy x-ray diffraction using the APS of ANL. The tested D1 will be shipped to ORNL for microstructural characterization and hardness measurements. Therefore, a total of eleven samples, i.e., nine SS-J2 tensile specimens and two 3-mm diameter discs, were shipped from INL to ORNL. ORNL has received the eleven samples in hot cells at 3025E. The nine SS-J2 tensile specimens are planned to be tensile-tested at room temperature in next few months right after the completion of instrument updates. 


\section{LANL SAMPLES}

\subsection{SELECTED LANL SAMPLES}

Three sets of LANL samples were identified, which are classified by their irradiation reactors, i.e., ATR, BOR-60, and Phénix. The samples and their respective conditions are listed in Table 3, together with their alloy compositions listed in Table 4.

Table 3. Selected LANL samples.

\begin{tabular}{|c|c|c|c|c|c|c|}
\hline Specimen type & Alloy & $\begin{array}{l}\text { Sample } \\
\text { ID }\end{array}$ & $\begin{array}{c}\text { Temperature } \\
\left({ }^{\circ} \mathrm{C}\right)\end{array}$ & $\begin{array}{l}\text { Dose } \\
\text { (dpa) }\end{array}$ & $\begin{array}{l}\text { Irradiation } \\
\text { reactor }\end{array}$ & Comment \\
\hline Type SS-J2 & \multirow{3}{*}{ T91 } & TA04 & 295 & 6.5 & \multirow{2}{*}{ ATR } & \multirow{2}{*}{$\begin{array}{l}\text { Tensile-tested } \\
\text { at } 25^{\circ} \mathrm{C}[14]\end{array}$} \\
\hline tensile & & TA\#1c ${ }^{a}$ & & 0 & & \\
\hline \multirow{4}{*}{$\begin{array}{c}\text { Ø3-mm TEM } \\
\text { discs }\end{array}$} & & T108 & 517 & 28 & \multirow{4}{*}{ BOR-60 } & \multirow{4}{*}{$\begin{array}{l}\text { Shared with } \\
\text { an IRP project }\end{array}$} \\
\hline & \multirow{3}{*}{ NF616 } & N71 & 425 & 19.6 & & \\
\hline & & N64 & 524 & 15.4 & & \\
\hline & & N133 & 517 & 28 & & \\
\hline \multirow{2}{*}{$\begin{array}{c}\text { Type SS-J3 } \\
\text { tensile or Ø3- } \\
\text { mm TEM discs }\end{array}$} & $800 \mathrm{H}$ & \multirow[b]{2}{*}{$\mathrm{TBI}^{\mathrm{b}}$} & \multirow{2}{*}{$\begin{array}{l}\sim 400 \text { and } \\
\sim 500^{c}\end{array}$} & \multirow{2}{*}{$\begin{array}{l}\text { Up to } \\
\sim 70^{c}\end{array}$} & \multirow[b]{2}{*}{ Phénix } & \multirow{2}{*}{$\begin{array}{l}\text { The Phénix } \\
\text { MATRIX } \\
\text { experiment }\end{array}$} \\
\hline & $\begin{array}{c}800 \mathrm{H}-\mathrm{TMP} \\
\mathrm{NF} 616\end{array}$ & & & & & \\
\hline
\end{tabular}

${ }^{a}$ Unirradiated control sample of the irradiated T91 (e.g., TA04).

${ }^{\mathrm{b}} \mathrm{TBI}$ - to be identified.

${ }^{\mathrm{c}}$ Planned temperatures and dose, unlike the other analyzed temperatures and doses.

Table 4. Compositions in weight percent (wt\%) of the LANL samples, with Fe as balance.

\begin{tabular}{|c|c|c|c|c|c|c|c|c|c|c|c|c|c|c|c|}
\hline Alloy & $\mathrm{Cr}$ & $\mathrm{Ni}$ & $\mathrm{Mn}$ & $\mathrm{Si}$ & $\mathrm{Ti}$ & $\mathrm{Al}$ & $\mathrm{V}$ & $\mathrm{W}$ & $\mathrm{Mo}$ & $\mathrm{Nb}$ & $\mathrm{Cu}$ & $\mathrm{C}$ & $\mathrm{N}$ & $\mathrm{P}$ & $\mathrm{S}$ \\
\hline T91 $^{*}$ & 9.22 & 0.18 & 0.46 & 0.24 & 0.002 & 0.009 & 0.24 & 0.013 & 0.96 & 0.063 & 0.087 & 0.052 & 0.057 & 0.016 & 0.001 \\
\hline NF616 & $\begin{array}{l}\text { The Phénix samples are from the same heat as the INL samples; the BOR-60 samples are likely to } \\
\text { be the ame heat as the INL samples, which is to be confirmed. }\end{array}$ \\
\hline $\begin{array}{c}\text { 800H/800- } \\
\text { TMP }\end{array}$ & \multicolumn{10}{|c}{ Thénix samples are from the same heat as the INL samples. } \\
\hline
\end{tabular}

* Also reported $0.002 \mathrm{O}$ and $0.021 \mathrm{Co}$. The steel was normalized at $1040^{\circ} \mathrm{C}$ for $1 \mathrm{~h}$ with air cooling and tempered at $760^{\circ} \mathrm{C}$ for $1 \mathrm{~h}$ with air cooling [14]. The T91 sample T108 is from the same provider as that of the INL samples, which is likely to be the same heat to be confirmed.

The selected ATR set of samples only have one T91 sample (i.e., TA04 in Table 3) irradiated at $\sim 295^{\circ} \mathrm{C}$ to $\sim 6.5 \mathrm{dpa}$, which has the lowest irradiation temperature in all the identified T91 samples. It complements the INL T91 samples listed in Table 1 as a baseline for comparison with NF616. The TA\#1c is an unirradiated control sample for TA04. The TA04 and TA\#1c samples were tensile-tested at room temperature, with the results reported by Maloy et al. [14].

The selected BOR-60 set of samples have T91 and NF616 samples irradiated to $15.4-28$ dpa at $425-524^{\circ} \mathrm{C}$, which are shared with an Integrated Research Project (IRP) under the Nuclear Energy University Program (NEUP) of U.S. Department of Energy. The NF616 was from the same source as that in the INL samples. They are likely to be the same heat, which is to be confirmed. The BOR-60 samples also include $800 \mathrm{H}$ samples, which had been sufficiently characterized. The results will be included in this project for comparison. The BOR-60 samples are all TEM disc type specimens and thus only provide hardness and microstructure results. There are multiple samples per condition for each alloy. Therefore, the sample ID of the BOR-60 samples characterized in this project may be different from that listed in Table 3. 
The selected Phénix set of samples include $800 \mathrm{H}, 800 \mathrm{H}-\mathrm{TMP}$, and NF616 samples irradiated up to 70 dpa at planned irradiation temperatures of $\sim 400$ and $\sim 500^{\circ} \mathrm{C}$. The analyzed irradiation temperatures and doses will be available later. The samples are in type SS-J3 miniature tensile specimens (similar to SS-J2 with a thicker thickness) and 3-mm diameter TEM discs, which are from the same heat as that in the INL samples.

\subsection{RECEPTION OF THE LANL SAMPLES AT ORNL}

The ATR and BOR-60 sets of samples are being shipped to ORNL. The Phénix set of samples are expected

to be available in early FY 2021, which may only provide some preliminary results for this project because of the timeline. 


\section{ORNL SAMPLES}

\subsection{SELECTED ORNL SAMPLES}

The selected ORNL samples include G92-2b and $800 \mathrm{H}$ samples irradiated to $0.46-14.66$ dpa at 400 to $\sim 720^{\circ} \mathrm{C}$ in the High Flux Isotope Reactor (HFIR) of ORNL, which are listed in Table 5, together with the alloy composition and condition in Table 6 . The G92-2b is a heat of optimized Grade 92, which was developed under the Advanced Reactor Technologies (ART) program [15]. It showed improved strength and creep resistance compared with conventional Grade 92 such as NF616. The AR2 and HG1 samples are $800 \mathrm{H}$ and $800 \mathrm{H}-\mathrm{TMP}$, respectively, from the same heat as the INL samples, as well as the Phénix set of samples, with composition listed in Table 2.

Table 5. Selected ORNL samples.

\begin{tabular}{|c|c|c|c|c|}
\hline Specimen type & Alloy & Sample ID & Temperature $\left({ }^{\circ} \mathrm{C}\right)$ & Dose (dpa) \\
\hline \multirow{4}{*}{ SS-J2 } & & GB03 & 400 & 0.52 \\
\cline { 3 - 5 } & \multirow{3}{*}{ G92-2b } & GB04 & $\sim 460$ & 7.44 \\
\cline { 3 - 5 } & & GB05 & 496.7 & 14.66 \\
\cline { 3 - 5 } & & GB10 & 683.3 & 0.46 \\
\cline { 3 - 5 } & & GB11 & $\sim 720$ & 7.44 \\
\cline { 3 - 5 } & & GB12 & $\sim 720$ & 14.63 \\
\hline \multirow{2}{*}{ SS-3 } & 800H & AR2 & 580 & 1.28 \\
\hline & $800 \mathrm{H}-\mathrm{TMP}$ & HG1 & 580 & \\
\hline
\end{tabular}

Table 6. Compositions in weight percent (wt\%) of the ORNL samples, with Fe as balance.

\begin{tabular}{|c|c|c|c|c|c|c|c|c|c|c|c|}
\hline Alloy & $\mathrm{Cr}$ & $\mathrm{Ni}$ & $\mathrm{Mn}$ & $\mathrm{Si}$ & $\mathrm{V}$ & $\mathrm{W}$ & $\mathrm{Mo}$ & $\mathrm{Nb}$ & $\mathrm{C}$ & $\mathrm{N}$ & $\mathrm{B}$ \\
\hline G92-2b $^{*}$ & 8.9 & 0.10 & 0.47 & 0.14 & 0.23 & 1.9 & 0.43 & 0.11 & 0.087 & 0.045 & $<0.002$ \\
\hline 800H/800-TMP & \multicolumn{10}{|c|}{ an tNL } \\
\hline
\end{tabular}

* The heat was normalized at $1080^{\circ} \mathrm{C}$ for $1 \mathrm{~h}$, followed by hot-rolling to $0.6^{\prime}$-thick plate from 1 " at $1080^{\circ} \mathrm{C}$ and water quench, and tempered at $750^{\circ} \mathrm{C}$ for $2 \mathrm{~h}$ with air cooling.

\subsection{RECEPTION OF THE ORNL SAMPLES}

The selected ORNL samples have been located. Some of the samples have been tensile-tested at the Irradiated Materials Examination and Testing (IMET) hot cell facility and being examined in the Low Activation Materials Design and Analysis (LAMDA) laboratory of ORNL, which is reported in a separate milestone report. 


\section{SUMMARY}

Ferritic-martensitic steel Grade 92, with T91 as a reference, together with austenitic stainless steel (or Incoloy Alloy) $800 \mathrm{H}$ and its GBE-treated version $800 \mathrm{H}-\mathrm{TMP}$, is investigated in this project. A total of fifteen Grade 92 samples, four T91 samples, six $800 \mathrm{H}$ and six $800 \mathrm{H}-\mathrm{TMP}$ samples were selected, which were primarily irradiated in the ATR, with the rest in the HFIR, BOR-60 and Phénix reactors. The irradiation temperature and dose conditions of the selected samples are plotted in Figure 1 . The Grade 92 samples have a large irradiation condition range, with the T91 samples consistent in a couple of the conditions. The $800 \mathrm{H}$ and $800 \mathrm{H}-\mathrm{TMP}$ samples have excellent consistency in the irradiation conditions. The selected samples of Grade 92 were from two or three heats, T91 from two heats, and $800 \mathrm{H}$ and $800 \mathrm{H}-\mathrm{TMP}$ from one heat.

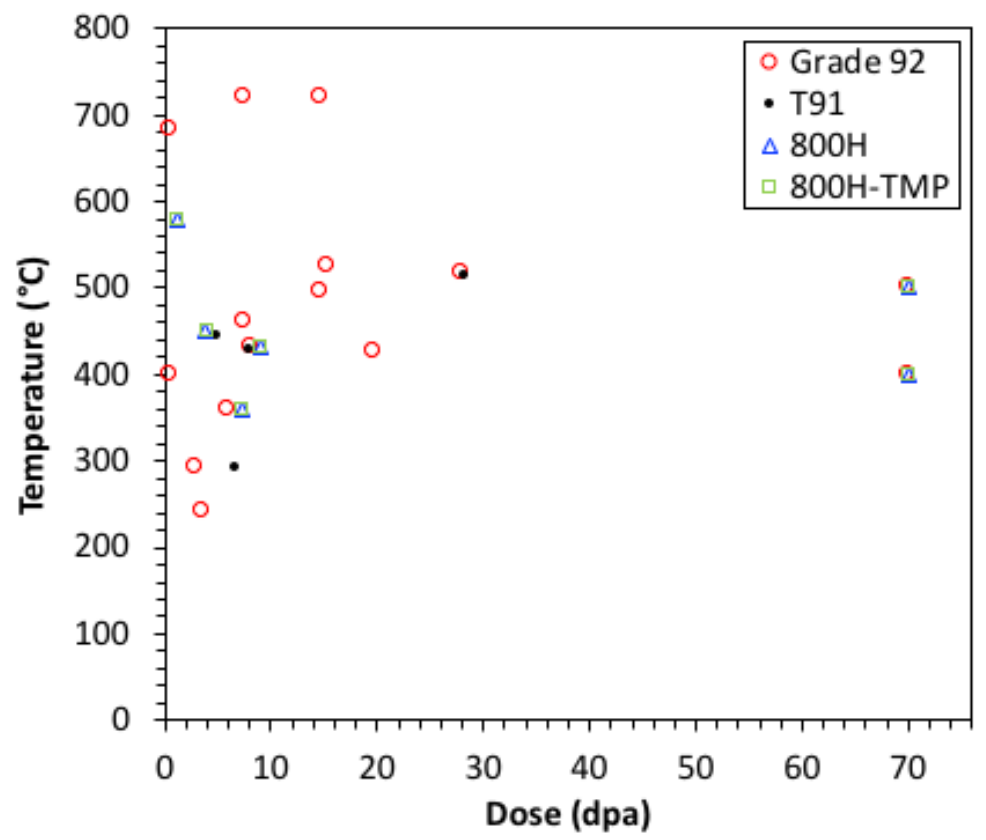

Figure 1. Irradiation temperature and dose conditions of the selected Grade 92, T91, 800H, and 800H-TMP samples.

All the INL samples, most of the ORNL samples, and part of the LANL samples have been received at the IMET hot cell facility and the LAMDA laboratory of ORNL. Post-irradiation examination of the received samples is in progress at ORNL. The effects of irradiation temperature, dose, reactor (e.g., dose rate, neutron-spectrum-induced difference in transmutation), TMP, and heats variation on the microstructures and mechanical properties of the samples will be evaluated. 


\section{REFERENCE}

[1] H.J. MacLean, K. Sridharan, T.A. Hyde, Irradiation Test Plan for the ATR National Scientific User Facility - University of Wisconsin Pilot Project, INL/EXT-09-15627, June 2008.

[2] L. Tan, T.R. Allen, An electron backscattered diffraction study of grain boundary-engineered Incoloy alloy 800H, Metall. Mater. Trans. A 36 (2005) 1921-1925.

[3] L. Tan, T.R. Allen, J.T. Busby, Grain boundary engineering for structure materials of nuclear reactors, J. Nucl. Mater. 441 (2013) 661-666.

[4] L. Tan, L. Rakotojaona, T.R. Allen, R.K. Nanstad, J.T. Busby, Microstructure optimization of austenitic alloy 800H (Fe-21Cr-32Ni), Mater. Sci. Eng. A 528 (2011) 2755-2761.

[5] L. Tan, K. Sridharan, T.R. Allen, The effect of grain boundary engineering on the oxidation behavior of Incoloy alloy 800H, J. Nucl. Mater. 348 (2006) 263-271.

[6] L. Tan, K. Sridharan, T.R. Allen, Altering corrosion response via grain boundary engineering, Mater. Sci. Forum 595-598 (2008) 409-418.

[7] L. Tan, K. Sridharan, T.R. Allen, R.K. Nanstad, D.A. McClintock, Microstructure tailoring for property improvements by grain boundary engineering, J. Nucl. Mater. 374 (2008) 270-280.

[8] L. Tan, T.R. Allen, Y. Yang, Corrosion behavior of alloy $800 \mathrm{H}(\mathrm{Fe}-21 \mathrm{Cr}-32 \mathrm{Ni})$ in supercritical water, Corros. Sci. 53 (2011) 703-711.

[9] R.K. Nanstad, D.A. McClintock, D.T. Hoelzer, L. Tan, T.R. Allen, High temperature irradiation effects in selected Generation IV structural alloys, J. Nucl. Mater. 392 (2009) 331-340.

[10] L. Tan, J.T. Busby, H.J.M. Chichester, K. Sridharan, T.R. Allen, Thermomechanical treatment for improved neutron irradiation resistance of austenitic alloy (Fe-21Cr-32Ni), J. Nucl. Mater. 437 (2013) $70-74$.

[11] K.L. Davis, B.M. Chase, T.C. Unruh, D.L. Knudson, J.L. Rempe, Evaluations of University of Wisconsin Silicon Carbide Temperature Monitors 300 LO and 400 LO B, INL/EXT-11-24226, December 2011.

[12] S. Wilson, et al., As-Run Thermal Analysis for the University of Wisconsin Experiment, Engineering Calculations and Analysis Report No. 3186, March 15, 2016.

[13] J. Brookman, et al., As-Run Physics Analysis for the University of Wisconsin Experiment in the ATR, Engineering Calculations and Analysis Report No. 3152, February 15, 2016.

[14] S.A. Maloy, T.A. Saleh, O. Anderoglu, T.J. Romero, G.R. Odette, T. Yamamoto, S. Li, J.I. Cole, R. Fielding, Characterization and comparative analysis of the tensile properties of five tempered martensitic steels and an oxide dispersion strengthened ferritic alloy irradiated at $\approx 295^{\circ} \mathrm{C}$ to $\approx 6.5 \mathrm{dpa}$, J. Nucl. Mater. 468 (2016) 232-239.

[15] L. Tan, P.J. Maziasz, T.-L. Sham, Report on the optimization and testing results of advanced ferritic/martensitic alloys, ORNL/TM-2012/288, September 14, 2012. 